\title{
The Effective Factors on Informal Economy in Developing Countries (Panel Data Model)
}

\author{
Majid Maddah (Corresponding Author) \\ Department of Economic, Faculty of Economic and Management \\ Semnan University, Iran \\ E-mail: majid.maddah@profs.semnan.ac.ir
}

Bahareh Sobhani

M.A. of Ecinomic Sciences, Semnan University, Iran

E-mail: sobhani.bahareh@yahoo.com

Received: September 20, 2014 Accepted: October 8, $2014 \quad$ Published: October 14, 2014

doi:10.5296/ijrd.v1i1.6437

URL: http://dx.doi.org/10.5296/ijrd.v1i1.6437

\begin{abstract}
A part of countries' economic activities is appertained to informal economy in which the activities done are not recorded in countries' formal statistics. Existence of the informal economy causes reduction in government incomes and has undesirable impact on policies' efficiency. Various factors are involved in formation and growth of the informal economy. In this article, the effect of macroeconomic variables on informal economy volume is investigated and analyzed for 98 developing countries using panel data model during 1999 to 2007. Estimation results show that there is a direct relationship between inflation and unemployment rate indices and the informal activities volume throughout countries, so that by one percent increase in inflation and unemployment indices, informal economy's share in gross domestic product of the investigated countries is increased by (0.19) and (0.04) percent, respectively. Economy's openness degree and the index presenting economic corruption and economy's openness degree interaction affect the informal economy volume negatively. Informal economy's elasticity relative to each of these indices is attained equal to (-0.05) and $(-0.04)$ respectively. This significant finding shows that although there is an indirect relationship between economy's openness degree and the informal economy volume, in countries where there is higher degree of economy openness and lower economic corruption simultaneously, informal economy's share in gross domestic product is also lower thereby economic corruption has a significant effect on informal economy volume. The present
\end{abstract}


article also investigates oil economies role in the informal economy volume. The model estimation results confirm higher the informal economy volume in oil-exporting countries relative to non-oil economies.

Keywords: Informal economy, Unemployment rate, Inflation rate, Economy's openness degree, Economic corruption, Interaction, Panel data

\section{Introduction}

Generally in all countries, a part of economic activities are carried out hidden in pursuit of evading the formal regulations or other enforced laws, which is called informal economy. In the informal economy activities are concealed from the government and hence are out of observation. Activities of a housewife, as it cannot be reported and also due to refraining to pay taxes or other duties, selling non-standard products, producing and exchanging illegal goods, organized crimes such as money laundering, smuggling goods, defraudation and embezzlement, are instances of informal economy. High volume of such activities in economy obstacles the right implementation of policies and distribution-dedication plans and reduces the efficiency of economic policies. Hence it is vital to identify the effective factors on its volume and apply appropriate solutions in order to decrease it in economies. In this regard, there is an essential question to discuss: which of the economic factors affect the volume of the informal economy? In order to give an appropriate answer to this question in this article, resting upon the informal economy literature and presenting a proper pattern, a panel data model for 98 developing countries during 1999 to 2007 is estimated, so to identify the economic factors affecting the volume of the informal economy in investigated countries and accordingly present policy solutions to reduce it.

\section{Review of the Previous Literature}

Informal economy literature deals with an expanded set of words and definitions of the informal economy. Among the most complete efforts accomplished in this field, Thomas's definition could be pointed out. Thomas (1991) explaining informal economy, states: "In broad concept, informal economy refers to all activities that are not entered in national accounts due to reasons." He then divides these activities into four groups: household, informal, irregular and illegal sector. The household sector feature is that its products are less supplied in the market and absence of price causes difficulty in evaluating their value and thus it is not possible to record them in national accounts. The informal sector usually includes retail producers and their employees and also trades people with no workers and trade services, transportation and other informal services personnel. The main feature of irregular sector activities is that although the act of producing the good or service is legal and permitted, the illegal act is committed during the production or distribution procedure. All the activities categorized in this sector are more or less accompanied by a kind of illegal matter such as tax or regulations (like work laws and safeguards in workhouses) evasion, forgery in social insurances and so on. The illegal sector products consist of illegal activities such as: theft, extortion, producing, buying and selling drugs, etc. Schneider (2010) defines the informal economy as a primary legal market of producing goods and services which are purposely hidden from government officers. Various factors are involved in formation and 
growth of the informal economy. From microeconomics point of view, everyone behaves rationally and compares the net profit of participating in formal and informal activities in order to decide where to take part. This issue has been investigated by Backer (1968) in the framework of a theoretical model. According to Backer, if net profit (income and expense difference) due to participation in illegal activities is higher, it is then economically justified. Backer, explaining his theory, attains the function $O_{i}=O_{i}\left(p_{i}, f_{i}, u_{i}\right)$ after maximizing a utility function. In this function $\mathrm{O}$ represents crime which includes any law-breaking behavior in society such as tax invasion that is a part of informal economy. Also, $\mathrm{p}, \mathrm{f}$ and $\mathrm{u}$ are respectively the possibility of condemnation due to participation in illegal activities, the amount of penalty and other effective factors on crime such as illegal incomes. According to this relation, the expected income due to participation in illegal activities is an effective factor on performing these activities. Illegal incomes existing in informal activities entail appropriate motive in the poor and the unemployed to compensate their restrictions and shortcomings through taking part in these activities. From macroeconomics point of view, researchers have been trying to empirically test the causal relation between economic indices and the size of the informal economy. Most of these studies have been done in the framework of hidden variables literature, using structural equations method. In these equations, in

addition to the informal economy estimation $(\eta)$, the effective factors such as the economic situation of the society $\left(x_{2}, x_{3}\right)$ have been identified via estimating the structural equation $\eta=\gamma_{11} x_{1}+\gamma_{12} x_{2}+\cdots+v$. Among the studies in this field, the following are pointed out (Note 1):

1) Inflation: Rise in general level of consumer goods prices means that there will be more difference between expenses and incomes of households. Inflation is a reflection of decrease in people's and firm's purchasing power and this increases the incentive to enter the informal activities in order to compensate the economic expenses due to inflation. Rise in the general level of prices leads to decrease in the purchasing power of the minimum income essential to subsist a living and this is an influential factor in justifying entrance to the informal activities. On the other side, increase in prices can lead to higher taxes inclusion on increased income of people and firms and therefore encourage participation in informal activities. In this regard, Gils, Tedds and Werneh (1999) mention inflation as a main cause of the informal activities emersion. Macias (2008) modeled the informal economy of Mexico, using structural equations approach. He introduced inflation as an effective factor on Mexico's informal economy growth along with other factors such as unemployment, taxes, wage level and enforced regulations and after estimating the model concluded: there is a reverse relation between inflation rate and the size of the informal economy. Inflation is a reflection of economic stability situation which by its increase small companies bust and by exiting the formal market, they tend to perform in informal market. In another study, Singh, Jain-Chandra and Mohmmad (2012) found mean inflation rate accompanied by five indices: income tax, GDP, economic corruption, government effectiveness and law governance, influential on the size of informal economy in 100 developing countries. 
2) Unemployment: Higher rates of unemployment can perform as an expanding factor on the informal sector, especially in developing countries. Unemployment and lack of occupation are equal to lack of income and required sources to entail a living. In this situation people have high incentives to participate in the informal activities. Frey and Weck-Hanneman (1984) count unemployment among the most important determining factors of the informal economy. DellAnno and Solomonl (2006) used USA economy's data and showed a direct and significant relation between unemployment and the informal economy and acknowledged unemployment as a main factor in emersion of USA's informal economy. Kanniainen, Paakkonen and Schneider (2004), used the information of 21 member countries in OECD during years 1989 to 2003 to illustrate that unemployment along with taxes, social security and tax morals have a significant impact on the size of the informal economy. Debrah and Faridi (2007), in order to justify the emersion of the informal economy cited: Informal sector is a source of occupation production and participating in this sector is considered as a way to fight poverty in developing countries. John-Uzma, Ochonma and Chimemela (2010) confirmed the direct relation of unemployment and other factors such as poverty, illiteracy, economic corruption, inflation and low wages with the size of the informal economy in Nigeria during years 1992 to 2006. They estimated the size of underground economy in Nigeria equal to (68.2) percent, using money-demand approach. In field of unemployment impact on the informal economy, there is another attitude that believes: Unemployment reveals the undesirable economic situation in a society. Regarding this view, rise in unemployment could be accompanied by recession and decrease in economic activities level in both formal and informal sectors. Hameter and Schneider (2007) and Macias (2008) confirmed the reverse relation between unemployment and the informal economy in Colombia and Mexico, respectively.

3) Economic corruption: In economic literature, corruption is usually known as using government power for personal profit. In different researches the relation between the informal economy and corruption is investigated. Kaufmann (1998) used statistical data of member countries in OECD and Latin America and transitory countries to show that by corruption expansion and weakened law, the informal economy volume increases. Tam and Choy (2002) investigated the impact of corruption on the choice between formal and informal sector in frame of a theoretical model and introduced economic corruption and bribery as main factors in employers' tendency to the informal activities. In another study, Manolas, Rontos, Sfakianakis and Vavouras (2013) investigated different factors on the informal economy for 19 member countries in OECD and Greece during years 2003 to 2008 using panel data model and concluded: High economic corruption accompanied by tax burden, severity of laws and regulations, and government size are among the most effective factors on the informal economy.

4) Economy's openness degree: Any trade restriction and closed trade sphere, rises incentives to get involved in illegal exchanges and goods trafficking. Trade obstacles increase formal import expenses to the country. In this situation, it will create high incentive in law-evading trade factors that are exempted from custom bureaucracy and paying taxes, to trade illegally. Goldberg and Pinelopik (2003) investigated the relation between trade enfranchisement and 
the informal sector in Colombia and Brazil and concluded: Increase in tariff rate and decrease in trade enfranchisement have increased the informal economy in these countries. In other related studies, effective factors on volume and size of the informal economy have been analyzed and investigated. For instance, Chong and Gradstan (2006) used a theoretical model to examine the relation between income inequality and informal economy and showed that: Income inequality and institutional weakness are reasons why the informal economy spreads. Along with these variables, other factors such as tax burden and market restrictions are also effective on the informal economy volume. Albercht, Navarro and Vroman (2009) examined the impact of two critical policies of labor market including income and wage tax and denotative tax on the informal economy of selected developing countries. The attained results show that: Denotative tax leads to decrease in productivity while wage tax increases it. Denotative tax policy reduces working hours in formal sector but raises the work time in the formal sector. Unemployment and eventually the informal economy volume are increased subject to wage tax policy. Putnins and Sauka (2011) estimated the informal economy volume in Baltic zone and claimed that: Small companies have more tendencies to participate in the informal economy. Tax burden is the most important factor in the informal economy formation and growth that causes error in measuring GDP in Baltic zone countries. Wanjie, Hon-Tat and Rasli (2011) introduced the role of government, regulations, tax, social character and economic issues as the most vital factors affecting the informal economy. Neck, Uwe-Wachter and Schneider (2012) used microeconomics theory to illustrate how tax avoidance affects tax evasion and informal economy. The asserted that not only direct and indirect taxes affect the informal economy, but also complication in tax system and market regulations have great influence on the informal economy. In Iranian economy, Pajuyan and Maddah (2006) in their study titled economic investigation on goods smuggling in Iran, presented tariff rate and tariff hedges, formal exchange rate relative to informal exchange rate and the penalty amount of smuggling as the critical factors on goods trafficking trend in Iran's economy.

\section{Model Specification}

Along with the target of this research, the below econometric model is considered in order to test the relation between macroeconomic variables and the size of the informal economy empirically.

$$
\text { Informal }_{i t}=\beta_{0}+\beta_{1} C P I_{i t}+\beta_{2} \text { Unemployment }+\beta_{3} X_{i t}+\eta_{i}+\varepsilon_{i t}
$$

Where $\mathrm{i}$ and $\mathrm{t}$ indices are respectively representing country $(\mathrm{i}=1, \ldots, 98)$ and time $(\mathrm{t}=1999, \ldots, 2007) . \quad \beta_{0}$ is the fixed coefficient of the model and Informal represents the share of the informal economy in country's GDP which is attained by Schneider's (2010) estimations. In this model CPI is the consumer price index in fixed prices of 2005, Unemployment is the unemployment rate (to percent) and $s$ is the residual and $X$ represents other variables explaining informal economy including economy's openness 
degree index (sum of exports and imports relative to GDP) and economic corruption perception index (which is in span of (0-10) based on data from the international organization of transparency with higher numbers showing less corruption and lower ones illustrating more corruption). $\eta$ is a term representing the fixed and random effect in panel data model.

Fixed effect approach considers $\eta_{i}$ as a fixed term where individual characters of sections

(countries) are different from each other. Random effect approach assumes $\eta_{i}$ as a random variable for each group. In the model based on fixed effect approach, the covariance of explanatory variable and $\eta$ is opposite zero and in the model based on random effect approach, the covariance of explanatory variable and $\eta$ is equal to zero. In addition to these variables, a dummy variable is used to examine the impact of oil revenues in oil-exporting countries on the size of the informal economy. For oil-exporting countries it equals 1 and for non-oil countries it is defined equal to zero. At the stage of model estimation, variables are entered into the model in logarithm form, so that the estimated coefficients represent the dependent variable elasticity relative to any of the explanatory variables.

As the information regarding each variable is used in time duration and in different sections at the stage of model estimation, in order to avoid the problem of spurious regression, first it is required to conduct the variables stationary test. In panel data various tests such as Levin, Lin and Chu (2002), Im, Pesaran and Shin (2003) are used to identify the stationary and non-stationary series or the ones having unit root. Among these, Levin, Lin and Chu (2002) enjoy more power and validity. The results from this test show that the logarithm of all the used variables in model is stationary. In estimating the model by panel data, first it is required to conduct two basic tests. First: Limer's F test which tests the fixed effect model against the model with pool data. In the fixed effect model, the differences between sections are considered that is called unrestricted regression. In the second model, the difference between sections is not considered which is called restricted regression. Second: Hausman (1998) test which is done after Limer test and it tests existence of random effects against fixed effects.

\section{Model Estimation and Empirical Analysis}

In this section, the results from estimating the specified model of relation between economic indices and the size of the informal economy are presented. In below tables, descriptive statistics, stationary test results of the used variables in the model and list of investigated countries are available. Table 3 shows the results of estimating different models in econometric model framework. In this table, the interaction term of economy's openness degree and economic corruption index is illustrated. This index is a synthesis of the effects of the two indices of economic corruption and economy's openness degree on the informal economy of countries. In the framework of research literature, the relation between economy's openness degree index and informal economy is expected to be indirect and the relation between economic corruption and the informal economy is predicted to be direct. Combining these two effects expresses that in a country not enjoying a desirable condition regarding economic openness degree and simultaneously having wider spread of economic 
corruption, the informal economy is expected to be more widespread. In fact, in a closed economy with high economic corruption (trade restrictions accompanied by more widespread bribery and other illegal payments in customs and institutions issuing import certificates), better background is provided for participation in the informal activities such as illegal trafficking (Note 2). According to the given definitions of the constituting indices of this index, it is predicted that there is an indirect relation between CT index and the informal economy. According to the results of table 3, direct relation between both inflation rate $\left(D \ln \left(C P^{\prime}\right)\right)$ and unemployment with the informal economy share in production of investigated countries is confirmed in all estimated models including the final model (4) (Note 3). This finding means that by increase in inflation and unemployment rate, the amount of participation in informal activities rises. In fact by rise in inflation rate, due to decrease in people's purchasing power and increase in production costs, people and firms have more incentive to enter the informal economic activities, so to compensate part of the imposed loss due to inflation. On the other hand, high unemployment rate encourages the unemployed to compensate their poverty through informal activities. Thus it seems that the informal economy is the asylum of people with low incomes, the poor and the unemployed in developing countries. This faces the government with difficulty in executing correct economic policies. In the final model, the coefficient of inflation rate and unemployment rate is attained equal to (0.19) and (0.04), respectively. These figures which are highly significant in statistical terms, express the informal economy's elasticity relative to each of the inflation rate and unemployment rate indices. By 1 percent increase in inflation rate and unemployment rate, the share of the informal economy in gross domestic product of developing countries rises by (0.19) and (0.04) percent, respectively. Thereby the effect of inflation rate is stronger than unemployment rate in spreading the informal economy in these countries. In estimated models, the relation between economy's openness degree and informal economy is attained negative and significant. The estimated coefficient for this index in the fourth model is (-0.05) which expresses indirect relation between economy's openness degree and informal economy. In fact countries with more economic restrictions in foreign trade sector and less economy's openness degree, have bigger the informal economy. Because trade restrictions increase legal exchanges costs and therefore raise people's incentives to participate in illegal activities.

Table 1. Obtained results from estimating the model of informal economy's share in gross domestic product in developing countries during (1999-2007)

\begin{tabular}{|l|l|l|l|l|}
\hline Explanatory variables & Model (1) & Model (2) & Model (3) & Model (4) \\
\hline Fixed figure & $\begin{array}{l}3.65 \\
(26.87)\end{array}$ & $\begin{array}{l}3.14 \\
(28.28)\end{array}$ & $\begin{array}{l}3.65 \\
(28.91)\end{array}$ & $\begin{array}{l}3.59 \\
(25.87)\end{array}$ \\
\hline $\ln (C P)$ & - & 0.08 & 0.17 & 0.19 \\
$(2.36)$ & $(5.07)$ & $(5.61)$ \\
\hline
\end{tabular}




\begin{tabular}{|c|c|c|c|c|}
\hline $\ln (U N)$ & - & $\begin{array}{l}0.04 \\
(5.4)\end{array}$ & $\begin{array}{l}0.03 \\
(4.37)\end{array}$ & $\begin{array}{l}0.04 \\
(4.84)\end{array}$ \\
\hline $\ln (M I)$ & $\begin{array}{l}0.004 \\
(0.74)\end{array}$ & - & - & - \\
\hline $\ln (T R)$ & $\begin{array}{l}-0.06 \\
(-2)\end{array}$ & - & $\begin{array}{l}-0.12 \\
(-8.7)\end{array}$ & $\begin{array}{l}-0.05 \\
(-2.21)\end{array}$ \\
\hline $\ln (C T)$ & $\begin{array}{l}-0.04 \\
(-1.78)\end{array}$ & - & - & $\begin{array}{l}-0.04 \\
(-2.22)\end{array}$ \\
\hline$D$ & $\begin{array}{l}0.36 \\
(2.82)\end{array}$ & $\begin{array}{l}0.32 \\
(2.63)\end{array}$ & $\begin{array}{l}0.34 \\
(2.7)\end{array}$ & $\begin{array}{l}0.35 \\
(2.65)\end{array}$ \\
\hline Limer F & $\begin{array}{l}585 \\
\text { (panel data) }\end{array}$ & $\begin{array}{l}741 \\
\text { (panel data) }\end{array}$ & $\begin{array}{l}9 \\
\text { (panel data) }\end{array}$ & $\begin{array}{l}932 \\
\text { (panel data) }\end{array}$ \\
\hline Hausman statistic & $\begin{array}{l}3 \\
\text { (random } \\
\text { effect) }\end{array}$ & $\begin{array}{l}2 \\
\text { (random } \\
\text { effect) }\end{array}$ & $\begin{array}{l}3 \\
\text { (random } \\
\text { effect) }\end{array}$ & $\begin{array}{l}4 \\
\text { (random } \\
\text { effect) }\end{array}$ \\
\hline Estimation approach & EGLS & EGLS & EGLS & EGLS \\
\hline$\overline{E^{2}}$ & 0.17 & 0.3 & 0.3 & 0.36 \\
\hline F statistic & 585 & 741 & 9.2 & 932 \\
\hline $\begin{array}{l}\text { Number } \\
\text { observations }\end{array}$ & 241 & 311 & 304 & 238 \\
\hline
\end{tabular}

Source: Research findings. 
Table 2. Descriptive statistical of model variables

\begin{tabular}{|l|l|l|l|l|l|}
\hline & IN & CP & $U N$ & $T R$ & CT \\
\hline Mean & 34.76234 & 92.21757 & 8.577406 & 80.36820 & 305.9238 \\
\hline Median & 32.90000 & 95.00000 & 8.000000 & 70.00000 & 220.4000 \\
\hline Maximum & 67.60000 & 131.0000 & 24.00000 & 220.0000 & 1230.800 \\
\hline Minimum & 11.90000 & 29.00000 & 1.000000 & 20.00000 & 44.20000 \\
\hline Std. dev & 12.73043 & 15.69198 & 4.622887 & 41.04351 & 240.8353 \\
\hline
\end{tabular}

Table 3. The results from stationary test of final model variables, Levin, Lin, Chu Test

\begin{tabular}{|l|l|l|}
\hline Variable & Statistic & Prob \\
\hline $\operatorname{Ln}(I N)$ & -16.5598 & 0.0000 \\
\hline $\operatorname{Ln}(C P)$ & -39.5115 & 0.0000 \\
\hline $\operatorname{Ln}(U N)$ & -7.06490 & 0.0000 \\
\hline $\operatorname{Ln}(T R)$ & -25.7721 & 0.0000 \\
\hline $\operatorname{Ln}(C T)$ & -14.1405 & 0.0000 \\
\hline
\end{tabular}

Source: Research findings. 
Table 4. The list of investigated countries

\begin{tabular}{|c|c|c|c|c|c|c|c|}
\hline 1 & Singapore & 26 & $\begin{array}{l}\text { Lao, People’s } \\
\text { Democratic } \\
\text { Republic }\end{array}$ & $\begin{array}{l}5 \\
1\end{array}$ & Marrakesh & 76 & Sri Lanka \\
\hline 2 & China & 27 & Lesotho & $\begin{array}{l}5 \\
2\end{array}$ & Madagascar & 77 & Nicaragua \\
\hline 3 & Vietnam & 28 & Dominican & $\begin{array}{l}5 \\
3\end{array}$ & Malawi & 78 & Senegal \\
\hline 4 & Saudi Arabia & 29 & Namibia & $\begin{array}{l}5 \\
4\end{array}$ & Bissau Guinea & 79 & Gambia \\
\hline 5 & Bahrain & 30 & Cameron & $\begin{array}{l}5 \\
5\end{array}$ & Tunisia & 80 & El Salvador \\
\hline 6 & Mongolia & 31 & Venezuela & $\begin{array}{l}5 \\
6\end{array}$ & Burundi & 81 & Congo Kinshasa \\
\hline 7 & Oman & 32 & Botswana & $\begin{array}{l}5 \\
7\end{array}$ & Brazil & 82 & $\begin{array}{l}\text { Central African } \\
\text { Republic }\end{array}$ \\
\hline 8 & Indonesia & 33 & Tropical Guinea & $\begin{array}{l}5 \\
8\end{array}$ & Colombia & 83 & Chad \\
\hline 9 & Iran & 34 & Guyana & $\begin{array}{l}5 \\
9\end{array}$ & Guinea & 84 & Congo \\
\hline 10 & Syria & 35 & Sudan & $\begin{array}{l}6 \\
0\end{array}$ & Ruanda & 85 & Gabon \\
\hline 11 & Jordan & 36 & Kenya & $\begin{array}{l}6 \\
1\end{array}$ & Mozambique & 86 & Benin \\
\hline 12 & Chile & 37 & Lebanon & $\begin{array}{l}6 \\
2\end{array}$ & Surinam & 87 & Zambia \\
\hline 13 & Kuwait & 38 & Fiji & $\begin{array}{l}6 \\
3\end{array}$ & Paraguay & 88 & Honduras \\
\hline
\end{tabular}




\begin{tabular}{|c|c|c|c|c|c|c|c|}
\hline 14 & Israel & 39 & Ecuador & $\begin{array}{l}6 \\
4\end{array}$ & Ethiopia & 89 & Guatemala \\
\hline 15 & Maurice & 40 & $\begin{array}{l}\text { Trinidad and } \\
\text { Tobago }\end{array}$ & $\begin{array}{l}6 \\
5\end{array}$ & Burkina Faso & 90 & Uruguay \\
\hline 16 & India & 41 & Algeria & $\begin{array}{l}6 \\
6\end{array}$ & Ghana & 91 & Thailand \\
\hline 17 & Argentina & 42 & Togo & $\begin{array}{l}6 \\
7\end{array}$ & Swaziland & 92 & Haiti \\
\hline 18 & Costa Rica & 43 & Egypt & $\begin{array}{l}6 \\
8\end{array}$ & Ivory Coast & 93 & Myanmar \\
\hline 19 & Malt & 44 & Bangladesh & $\begin{array}{l}6 \\
9\end{array}$ & Mali & 94 & Nigeria \\
\hline 20 & $\begin{array}{l}\text { United Arabic } \\
\text { Emirates }\end{array}$ & 45 & Cape Verde & $\begin{array}{l}7 \\
0\end{array}$ & Uganda & 95 & Tanzania \\
\hline 21 & Yemen & 46 & New Guinea & $\begin{array}{l}7 \\
1\end{array}$ & Angola & 96 & Peru \\
\hline 22 & Cyprus & 47 & Pakistan & $\begin{array}{l}7 \\
2\end{array}$ & Niger & 97 & Panama \\
\hline 23 & South Africa & 48 & Nepal & $\begin{array}{l}7 \\
3\end{array}$ & Belize & 98 & Bolivia \\
\hline 24 & Mexico & 49 & Jamaica & $\begin{array}{l}7 \\
4\end{array}$ & Sierra Leon & & \\
\hline 25 & Malaysia & 50 & Mauritania & $\begin{array}{l}7 \\
5\end{array}$ & Philippines & & \\
\hline
\end{tabular}

In the final model, the coefficient of interaction index is obtained equal to $(-0.04)$ which is negative, as expected, and is highly significant in statistical terms. By comparing the estimated coefficients for economy's openness degree and interaction index it could be asserted that: The size of informal economy in countries with less economy's openness degree and simultaneously less amount of economic corruption index (that is more economic corruption) is bigger than countries with the same openness degree. Hence, in addition to 
economy's openness degree which reflects trade policies, the amount of existing economic corruption in the society is also effective on the size of informal economy and this shows the role if economic corruption in informal economy volume and is a critical finding for policy-making system. The eighth line in estimated models illustrates the relation between the dummy variable for oil-exporting countries and informal economy's share in countries' production. The coefficient of this variable is (0.35) which its statistical significance is highly confirmed. The positive sign of this variable shows that among the investigated countries, the size of informal economy in oil-exporting countries is bigger than the others.

\section{Results and Suggestions}

Existence and growth of the informal economy cause decrease in government revenues and undesirable performance in economic policies. Part of economic activities in developing countries is appertained to the informal economy. In this article, the impact of macroeconomic variables such as inflation and unemployment rate along with economy's openness degree and economic corruption indices on informal economy's share in 98 developing countries during (1999-2007) has been tested empirically in the framework of panel data model. The results of the final model estimation confirm the direct relation between inflation rate and unemployment with the informal economy's share in the investigated countries. In this model, the elasticity of informal economy's share in gross domestic product of countries relative to the two macroeconomic key variables, inflation and unemployment rate, is obtained equal to (0.19) and (0.04), respectively. Thus it can be stated that economic condition of developing countries has a positive and significant impact on the informal economy volume. On one side, inflation decreases the purchasing power of people and leads to spread of poverty and indigence. On the other side, with unemployment, there is no job and income to subsist people's lives in society. These circumstances encourage people to participate in the informal activities in order to get rid of the restrictions. The result attained from the final model expresses that the informal economy reflects the economic conditions of developing countries. This article also investigates the impact of trade policies on the size of the informal economy. The results of model estimation confirm the reverse and significant relation between economy's openness degree index and the informal economy volume with the coefficient of $(-0.05)$ for the investigated countries. Thus, in countries with more trade restrictions and less economic enfranchisements, there is a better background for participation in the informal activities. As with lower economy's openness degree, the cost of various domestic and foreign exchanges rises, this situation provides a suitable condition for illegal activities that have less regulations and restrictions. The interaction of economy's openness degree and economic corruption is investigated via entering the interaction index. The obtained results from estimating the model confirm the negative and significant relation between this index and the size of informal economy. The coefficient of this index is equal to $(-0.04)$ which is statistically and economically significant. Comparing the estimated coefficient for interaction and the estimated coefficient for economy's openness degree index expresses lower amount for the interaction index relative to economy's openness degree. This result is a critical finding in policy-making level. In fact, in countries where there is higher economy's openness degree and simultaneously less economic corruption, the size of the 
informal economy is smaller and hence economic corruption is among the vital factors in formation and growth of the informal economy in the investigated countries. Another model estimation outcome is the positive and significant impact of oil on the size of the informal economy. This issue is examined via entering a dummy variable into the model. The results attained from this article illustrate the impact of economic variables on the volume of the informal economy activities in developing countries. These activities include a wide range from housewives' products, informal business, evading government laws and regulations and illegal activities which cause decrease in government revenues, no recording of all economic activities in formal statistics, inefficiency of economic policies, increase in private and public sector costs imposed on the society, chasing a solution for illegal activities, fighting and controlling informal proceedings. In order to reduce these costs, it is required to provide needed legal, economic and institutional commitments to decrease the informal economy activities' share in the society.

\section{References}

Albrecht, J., \& Navarro, L., \& Vraman, S. (2009). The effect of labor market policies in an economy with an informal sector. Economic Journal, Royal Economic Society, 119(539), 1105-1129.

Becker, G. (1968). Crime and punishment: an economic approach. Journal of Political Economy, 76, 1169-1271. http://dx.doi.org/10.1086/259394

Choi, J., \& Thum, M. (2002), Corruption and the underground economy. CES ifo Working Paper Series, 663.

Frey, B. S., \& Weck-Hanneman, H. (1984). The hidden economy as an unobservable variable. European Economic Review, 26, 33-53. http://dx.doi.org/10.1016/0014-2921(84)90020-5

Goldberg, K. (2003). The response of the informal sector to trade liberalization. Journal of Developing Economics, 72(2), 43-94.

Johnson, S., Kaufmann, D., \& Zoido-Lobaton, P. (1998). Regulatory discretion and the unofficial economy. American Economic Review, 88, 387-392.

Johnuzoma, I., \& Chiemela, G. (2010). Non-tax factors as critical determinants of the size of underground economy in Nigeria: imperative for policy action. Journal of Emerging Trends in Economics and Management Sciences, 1(1), 13-22.

Kanniainen, V., \& Paakkonen, J., \& Schneider, F. (2004). Fiscal and ethical determinants of shadow economy: theory and evidence. Discussion Paper, 30.

MACIAS, B. J. (2008). Modeling the informal economy in Mexico, a structural equation approach. Muni Munich Personal RePEc Archive.

Manolas, G., \& Rontos, K., \& Sfakianakis, G., \& Vavouras, I. (2013). The determinants of the shadow economy: the case of Greece. International Journal of Criminology and Sociological Theory, 6(1), 1036-1047. 


\section{Macrothink}

International Journal of Regional Development ISSN 2373-9851 2014, Vol. 1, No. 1

Neck, R., \& Uwewachter, J., \& Schneider, F. (2012). Tax avoidance versus Tax evasion: on some determinants of the shadow economy. International Tax and Public Finance, 19(1), 104-117. http://dx.doi.org/10.1007/s10797-011-9197-5

Pajuyan, J., \& Maddah, M. (2006). Economic Investigation of Goods Smuggling in Iran. Economic Research, 70, 23-43.

Putnins, T., \& Sauka, A. (2011). Size and determinants of shadow economies in the Baltic States. Baltic Journal of Economics, 11(2), 5-25. http://dx.doi.org/10.1080/1406099X.2011.10840498

Schneider, F., Buehn, A., \& Montenegro, E. (2010). New estimates for the shadow economies all over the world. International Economic Journal, 24(4), 443-461. http://dx.doi.org/10.1080/10168737.2010.525974

Thomas, J. J., Ryscavage, R., \& Siesto, V. (1991). Informal economic activity. LSE handbooks in economics. Prentice-Hall Press .

Wanjie, S., \& Hontat, H., \& Rasli, A. (2011). Underground economy: definition and causes. Business and Management Review, 1(2), 14-24.

\section{Notes}

Note 1. Different variables affect the size of informal economy. Here, regarding the comparison between the results of estimating various models and inside the article's title frame, merely the research literature related to the impact of two significant macroeconomic indices, inflation and unemployment, as well as economy's openness degree and economic corruption index on the size of informal economy is presented.

Note 2. This index is obtained after estimating various models.

Note 3. In model (1) the relation between the sum of inflation and unemployment rates, which is introduced as misery index in economic literature, and other indices with informal economy share in gross domestic product of countries is tested. According to the results obtained from estimating model (1) the direct relation between misery index and the size of informal economy exists in the investigated countries, but statistically, the coefficient of this index is not significant.

\section{Copyright Disclaimer}

Copyright for this article is retained by the author(s), with first publication rights granted to the journal.

This is an open-access article distributed under the terms and conditions of the Creative Commons Attribution license (http://creativecommons.org/licenses/by/3.0/). 